\title{
Sengketa Tanureal: Refleksi Pertentangan Sentralisme Hak Menguasai Negara dalam UUPA dengan Kepentingan Masyarakat Adat
}

\author{
M. Syamsudin \& Ahmad Basuki
}

\begin{abstract}
The UUPA is a transitional act product which is made to change the characteristic of colonial Law of agrarian field into the agrarian law which is in accordance with the form and idea of Indonesia Republic Unitary State. In practice, during the new order regime, the authorities abused the State Authorization Right and gave the investors the privileges of controlling the agrarian sources. As a consequence, the existency and community role of the custom were getting marginilized and felt at a disadvantage. This reality frequenthy triggered to cause the tenureal disputes between the investors and the custom community which, in general, enabled to threat the integrity of national teritory/ unity. In the effor of preventing the recurrence, the UUPA needs reforming the characteristic of agrarian law which not only accomodating but also warranting the interests of custom community. Pluralism of agrarian law should reflect more the spirit of Unity in diversity.
\end{abstract}

\section{Pendahuluan}

Sejak semula para pendiri negara (the founding fathers) Republik Indonesia menyadari bahwa bangsa Indonesia adalah bangsa yang majemuk. Semboyan Bhinneka Tunggal Ika merupakan wujud penghormatan dan apresiasi filosofis bangsa indonesia atas kemajemukan atau keanekaragaman yang dimilikinya. Keanekaragaman yang dimaksud dapat dilihat pada realitas yang ada dalam berbagai kelompok masyarakat adat, yang kini termasuk dalam bagian integral dari bangsa Indonesia yang terdiri dari berbagai suku

bangsa, kelompok penutur bahasa, penganut ajaran agama dan kepercayaan yang berbeda-beda. Keanekaragaman bangsa Indonesia ini akhirnya bermuara pada perbedaan adaptasi interaktif suatu komunitas terhadap lingkungan sekitamya. Hal ini pada kenyataannya telah melahirkan komunitaskomunitas adat yang lebih memiliki kearifan lingkungan dan mode of production yang khas, berbeda satu dengan yang lain.

Dalam pejalanan kehidupan bernegara, untuk dan atas nama pembangunan, pemerintah 
sebagai mandataris pemegang kedaulatan rakyat telah mengeluarkan banyak kebijakan dan hukum yang secara tidak adil dan tidak demokratis mengambil alih hak asal-usul; hak atas tanah wilayah adat; hak untuk melindungi dan menegakkan sistem nilai, ideologi dan adat istiadat; hak ekonomi; serta hak yang paling utama adalah hak politik masyarakat adat.

Perangkat kebijakan dan hukum yang memaksakan uniformitas dan bersifat hegemonistik diciptakan dan dimanfaatkan secara sistematik untuk memperkuat posisi negara atas masyarakat. Dalam kebijakan dan hukum yang demikian inilah, maka realitas simbolik yang ada bukan lagi keanekaragaman melainkan keseragaman. Realitas empirik yang mencerminkan adanya kebinekaan secara perlahan-lahan telah diganti dengan realitas simbolik kemanunggalan negara. Tidak ada kekuatan lain selain kekuatan dan kepentingan negara. Akibat dari fenomena tersebut masyarakat atau komunitas adat telah menjadi salah satu pihak yang paling dikorbankan dan dirugikan walaupun secara empirik mereka merupakan elemen terbesar dalam struktur negara Indonesia, namun dalam proses pembuatan kebijakan dan hukum mereka tidak mempunyai akses sama sekali, sehingga tuntutan dan aspirasinya tidak terakomodir dalam kebijakan ataupun dalam produk hukum yang ada.
Pada tataran implementasi kebijakan dan hukum yang demikian itu akan semakin "mengasingkan" eksistensi dan peranan dalam kehidupan mereka. Kecenderungan itu sudah mulai nampak dengan munculnya sebutan "peladang berpindah", "perambah hutan", "masyarakat primitif", dan "masyarakat terasing." Walaupun demikian komunitas adat masih tetap survive, meskipun dalam suasana ketidakberdayaan, baik secara siil maupun struktural.

Gerakan reformasi yang mengakhiri rejim Orde Baru dan menggantikannya dengan Era Reformasi Total merupakan kesempatan emas bagi komunitas adat untuk bangkit guna menuntut kembali hak-hak mereka yang selama ini dirampas oleh rejim Orde Baru dengan memanfaatkan Sentralisme Hak Menguasai Negara (selanjutnya disebut HMN) dalam Undang-Undang No. 5 Tahun 1960 tentang Pokok-Pokok Agraria (selanjutnya disebut UUPA). Tuntutan mereka inilah yang akhirnya memicu munculnya berbagai sengketa antara masyarakat adat dengan orang atau badan hukum pemegang izin, konsesi, ataupun hak-hak lainnya yang diberikan oleh pemerintah untuk mengolah dan mengeksplorasi sumber-sumber agraria yang ada di lingkungan itu. Sengketa pertanahan yang bersumber pada alas hak yang berbeda ini lazimnya disebut sebagai Sengketa Tenureal.'

'Sengketa tenureal adalah sengketa atas sebidang tanah beserta apa yang tumbuh di atasnya dan apa yang terkandung di dalamnya. Sengketa terjadi karena adanya pemberian hak baru atas sebidang tanah tersebutkepada perusahaan bermodal besar atau proyek pemerintah tertentu padahal sebelumnya sudah ada hubungan yang sangat kuat antara penduduk dengan tanah tersebut. Umumnya diketahui bahwa sengketa tenurial bersifat struktural yang dimulai karena penggunaan kekuasaan yang besar. Pada tingkat mikro, konfik tenurial berwujud saling klaim atas lokasi yang sama dengan alas hak yang berbeda oleh intsitusi yang berbeda. 
Bagaimana UUPA sebagai ketentuan induk dalam kebijakan pertanahan mengatur wewenang negara untuk mengatur dan menyelenggarakan peruntukkan, penggunaan, dan persediaan tanah sehingga dalam praktek banyak menimbulkan permasalahan, di antaranya adalah sengketa tenureal.

Dengan telaah kritis atas UUPA tersebut, selanjutnya akan dapat diformulasikan kembali bagaimana UUPA dibangun (reform) sesuai dengan corak realitas masyarakat yang majemuk.

\section{UUPA: Landasan Kebijakan Agraria yang Sentralistik}

Undang-undang No. 5 Tahun 1960 tentang Pokok-Pokok Agraria adalah produk perundang-undangan yang dibuat untuk mengubah karakter hukum kolonial di bidang agraria, menuju hukum agraria yang sesuai dengan bentuk dan cita-cita Negara Kesatuan Republik Indonesia. Oleh karena itu, pembentuk UUPA bermaksud untuk membawa rakyat ke arah keadilan sosial, kemakmuran dan kemajuan melalui penataan ulang mengenai penguasaan, peruntukkan, pengelolaan dan pemanfaatan sumbersumber agraria. Maksud pembentuk UUPA itu tercermin dari langkah sentralisasi kekuasaan di bidang agraria ke tangan negara, yang dalam prakteknya dilaksanakan oleh pemerintah (pusat). Hal ini tampak dari rumusan Pasal 2 ayat (1):
Atas dasar ketentuan Pasal 33 ayat (3) Undang-undang Dasar, dan hal-hal yang sebagai yang dimaksud dalam Pasal 1, bumi, air, dan ruang angkasa, termasuk kekayaan alam yang terkandung di dalamnya itu pada tingkatan tertinggi dikuasai oleh Negara, sebagai organisasi kekuasaan seluruh rakyat.

Sentralisme kekuasaan sebagaimana dimaksud dalam Pasal 2 ayat (1) tersebut apabila dikaji secara historis tidak dapat dilepaskan dari kuatnya pengaruh sosialismetotaliter yang berkembang pada saat pembentukan UUPA. Setelah negara berhasil "menguasai" seluruh sumber-sumber agraria, selanjutnya negara mengadakan pengaturan dan penyelenggaraan mengenai pengadaan, peruntukan dan pemanfaatan sumber-sumber agraria. Oleh karena itu, dalam Pasal 2 ayat (2) ditegaskan:

Hak menguasai dari negara termaksud ayat (1) pasal ini memberi wewenang untuk:

1. mengatur dan menyelenggarakan peruntukan, penggunaan, persediaan dan pemeliharaan bumi, air dan ruang angkasa tersebut;

2. menentukan dan mengatur hubunganhubungan hukum antara orang-orang dengan bumi, air dan ruang angkasa; dan

3. menentukan dan mengatur hubungan hukum antara orang-orang dan perbuatanperbuatan hukum mengenai bumi, air, dar ruang angkasa.

Di satu pihak masyarakat mengkliam atas dasar aturan dan/ atau hukum adat setempat yang telah lama bertumbul kembang sejak dulu. Di pihak lain pemegang konsesi mengklaim atas dasar hak yang diberikan oleh negari beralaskan sejumlah peraturan dan perundang-undangan dari hukum formal yang berlaku. Llihat Soetandyı Wignyosoebroto, "Menggugat: Masyarakat Adat Terhadap Negara", Panitia Bersama Sarasehan dan Kongre Masyarakat Adat Nusantara 1999, Jakarta, 1999, him.183. 
Banyak pendapat yang mengatakan bahwa ketentuan Pasal 2 ayat (2) tersebut merupakan tafsir dari Pasal 2 ayat (1) bahwa negara bukan merupakan pemilik (domein) dari segala sumber-sumber agraria, melainkan sebatas sebagai penguasa (beheerder). ${ }^{2}$ Oleh karena itu, secara prinsipil sebenarnya pemilikan hak atas tanah beserta sumbersumber agraria lainnya dikembalikan menurut asas dan praktik hukum adat yang bemuansa kerakyatan dan kekhasan masing-masing. Negara, dalam hal ini pemerintah hanya memfasilitasi untuk mendelegasikan sebagian kewenangan yang dimilikinya tadi kepada komunitas adat. Hal ini tampak secara tegas dinyatakan dalam Pasal 2 ayat (4), yaitu:

Hak menguasai dari negara tersebut di atas pelaksanaannya dapat dikuasakan kepada daerah-daerah swatantra dan masyarakat-masyarakat hukum adat, sekedar diperlukan dan tidak bertentangan dengan kepentingan nasional dan menurut ketentuan peraturan pemerintah.

Pemahaman terhadap beberapa ketentuan UUPA tersebut di atas telah menimbulkan banyak tafsir, khususnya telah disalah tafsirkan dan diselewengkan oleh hegemoni rejim Orde Baru.
Konsep Hak Menguasai Negara dalam UUPA: Antara Realitas Simbolik dan Realitas Empirik

Perkembangan gagasan tentang politik agraria Indonesia pasca kolonial menemukan bentuknya dengan dirumuskannya UUPA. Maksud pembentukan UUPA sejak awal adalah sebagai umbrella provision di bidang agraria sekaligus merupakan peraturan organik dalam melaksanakan amanat. Pasal 33 ayat (3) Undang-Undang Dasar 1945.

Pasal 33 ayat (3) UUD 1945 menentukan, bahwa "bumi, air dan kekayaan alam yang terkandung di dalamnya dikuasai oleh negara dan dipergunakan untuk sebesar-besarnya kemakmuran rakyat". Konsep "negara menguasai" bumi, air dan kekayaan alam yang terkandung di dalamnya, dalam wacana biasa disebut HMN merupakan landasan konstitusional dalam penguasaan dan pemanfaatan sumbersumber agraria sebagaimana yang tertuang dalam Pasal 2 ayat (1) UUPA.

Cita-cita ideal yang terkandung dalam konseps HMN adalah"menempatkan negara sebagai sentral yang mengatur pemanfaatan kekayaari negeri untuk kemakmuran rakyat. Untuk mencapai cita-cita ini dengan tegas mengemukakan prasyarat adanya sebuah "negara yang kuat", ${ }^{3}$ karena akan menjadi

2Periksa Soetandyo Wignyosoebroto, "Pembaharuan Agraria: Apa yang Perlu Diagendakan", dalam Usulan Revisi UUPA, Konsursium Reformasi Hukum Nasional dan Konsursium Pembaharuan Agrana, Jakarta, 1998, hlm. 240.

${ }^{3}$ Konsepsi negara yang mengatasi warganya berasal dari pandangan Hegel yang memandang negara sebagai penjelmaan dari ide universal, yaitu menciptakan masyarakat yang lebih baik. Karena itu Negara perlu memperoleh kekuasaan yang besar agar bisa bekerja untuk mewujudkan ide besar dan universal tersebut. Tetapi perlu dicatat bahwa dalam pandangan Hegel kekuasaan negara yang besar tersebut diabdikan bagi kebaikan masyarakat dengan membimbing masyarakat yang sekarang menuju ke masyarakat yang sempurna di masa mendatang. Ini adalah tugas sejarah negara. Negaramodem, menurut konsep Hegel memiliki wewenang untuk memaksakan kemauannya kepada warga negara. Karena itu, negara harus dipatuhi oleh warganya, 
sentral dari segala hal —paling tidak dalam hal ini menyangkut masalah keagrariaan. $\mathrm{Di}$ sisi lain, ide/cita-cita ini juga mensyaratkan adanya suatu bentuk "Negara yang Netral", ${ }^{4}$ bebas dari kepentingan lain, selain untuk kepentingan mensejahterakan rakyat. Padahal kenyataan yang terjadi tidaklah sebagaimana yang diidealkan. Realitas yang terjadi negara dalam melaksanakan tugasnya sering diboncengi oleh. sejumlah kepentingan kelompok atau individu yang mengatasnamakan kepentingan mereka dengan kepentingan umum atau kepentingan rakyat atau kepentingan negara. ${ }^{5}$

Dalam praktek, sulit merumuskan suatu batasan atau definisi tentang kepentingan umum. Untuk kepentingan para pelaksana pemerintahan diperlukan perumusan yang jelas agar dapat lebih mudah dalam pelaksanaanya. Hal ini pun terjadi pada tataran teoritik bahwa para ahli ilmu sosial dalam 150 tahun terakhir tidak mampu memberikan sumbangan yang konkrit bagi praktek-praktek pemerintahan tentang penyelenggaraan kepentingan umum. Rumusan-rumusan yang pernah ada tentang kepentingan umum sangat berbeda-beda bahkan kadang-kadang kontradiktif. ${ }^{6}$

Walter Lippman, dikutip Abidin, mewakili aliran klasik memberikan definisi kepentingan umum sebagai:?
What men would choose if they saw clearly, thought rationally, and acted disinterest- edly and benevolenly. (Apa yang seharus. nya oleh seseorang dipilih bila mereke melihat sesuatu secara jelas: mempertimbangkan sesuatu secara logis: masuk akal, dan bertindak dengar dilandasi penuh keikhlasan dan motivas berbuat kebajikan.

bukan sebaliknya. Sebagai lembaga yang mengatasi masyarakat, negaralah yang yang tahu segala hal yan! baik bagi masyarakat secara keseluriuhạn. Pandangan Hegelian yang menegaskan perlunya suatu negari yang kuat diterüskan oleh pandangan negara organik, yang melihat negara sebagai lembaga yang memilik kemauan sendiri. Periksa Arief Budiman, Teori Negara: Negara, Kekuasaan dan Ideologi (Jakarta: Gramedic 1996).

4Konsep negara yang netral, khususnya menjalankan misi kesejahteraan masyarakat sebagai kompron dari berbagai kepentingan, merupakan konsep kaum pluralis. Kaum pluralis memang melihat negara sebag: sebuah alat untuk memperjuangkan kepentingan bersama darikelompok-kelompok yang ada dalam masyarak: yang membangun kompromi di antara mereka. Periksa ibid.

${ }_{5}^{5} \mathrm{Hal}$ ini sesuai dengan pandangan Mills yang menegaskan bahwa negara bukanlah lembaga yang netra Mills melalui studinya menunjukkan bahwa ada sebuah kelompok elite penguasa yang biasanya menguas; negara. Negara kemudian selalu diupayakan untuk melayani kelompok penguasa ini, yang merupakan kelompc paling kuat dalam negara tersebut. Negara tidak pemah menjadi titk temu dari pelbagai kepentingan yang ad dalam masyarakat. Pandangan Mills ini memperkuat pandangan Marxis yang berpendapat bahwa negar mengabdikan dirinya bagi kepentingan klas yang berkuasa dalam masyarakat. Periksa ibid.

${ }^{6} \mathrm{HE}$ Zenal Abidin, "Kepentingan Umum sebagai Alasan Pencabutan/Pembebasan Hak atas Tanah . Daerah Istimewa Jogyakarta", Laporan Penelitian Lembaga Penelitian UII Jogjakarta, 1991.

'Lippan, W., dalam Kenneth., Administrative Law, West Publishing Co, New York, 1992, hlm. 110. 
J.A.W. Gun menyatakan bahwa kepentingan umum tidak lain adalah paham kemanfaatan (utilitarianism). J.W.R Cox menyatakan bahwa inti dari konsep kepentingan umum adalah "mayoritas" seperti yang dikemukakan Robert Miewald yang menyatakan bahwa kepentingan umum adalah:

The closest one can come to it is the will of the majority of voters at any particular time. (Sesuatu yang paling mendekati pada pengertian kepentingan umum adalah kehendak dari kelompok terbesar pemberi suara pada suatu waktu tertentu). ${ }^{8}$

Untuk masalah-masalah spesifik yang berkaitan dengan perumusan kebijakan pemerintah dapat digunakan formulasi untung rugi atau cost-benefit analysis dalam menentukan apakah sesuatu peraturan/ kebijakan menunjang pengembangan kepentingan umum atau sebaliknya merugikan kepentingan umum. Keuntungan (benefit) harus pula dipertanyakan untuk siapa keuntungan tersebut sebagian besar dirasakan? Dari segi biaya (cost) selain perhitungan ekonomis yakni seberapa besar keuntungan-keuntungan akan diperoleh, harus pula diperhitungkan biaya yang menjadi beban masyarakat (social cost) yang mungkin tidak disadari misalnya, kualitas hidup yang merosot, pengangguran, pencemaran lingkungan, dan polusi budaya. Analisis untung rugi ini perlu dilakukan dalam setiap pengambilan keputusan seperti pembuatan jalan tol, jembatan, bendungan, lapangan, dan pengembangan pusat-pusat wisata. ${ }^{9}$

Setelah selama enam tahun UUPA berlaku, pada saat pemerintahan Orde Lama sedang berupaya menjalankan sejumlah amanat yang dikandung dalam UUPA untuk mensejahterakan dan membebaskan rakyat Indonesia dari penindasan oleh manusia terhadap manusia (exploitation de l'homme pour l'homme), khususnya melalui program land reform sebagai langkah awal, konflik kepentingan atas sumber-sumber agraria di Indonesia memuncak dan mendapatkan ruang konflik yang lebih besar dalam konflik elit politik yang berujung dengan peristiwa 1965-1966, -jatuhnya Orde Lama ke tangan rejim Orde Baru.

Kebijakan Orde Baru dalam pembangunan yang menekankan pada orientasi pembangunan ekonomi kapitalis membawa konsekuensi munculnya kecenderungan untuk mencapai pertumbuhan ekonomi yang tinggi. Hal inilah yang menjadikan pembangunan ekonomi nasional terintegrasi ke dalam sistem ekonomi global. Dalam rangka itu, maka pemerintah membutuhkan seperangkat peraturan yang dapat memfasilitasi kebutuhan dan kepentingan pembangunan. Dalam konteks ini hukum dianggap sebagai perangkat pembangunan, "law as atool of social engineering ${ }^{n},{ }^{10}$ sebagaimana yang kemudian dikembangkan menjadi aliran developmentalism.

\section{\&lbid.}

${ }^{9}$ Quade, E, S, Analysis for Public Decicion, North-Halland, New York, 1982, him. 117, 240.

${ }^{10}$ Sesungguhnya social engeenering adalah tindakan rasional yang biasa, tetapi di Indonesia sering kualifikasikan sebagai "jahat". Menurut Roscoe Pound social engeenering adalah usaha rasional untuk mengamankan nilai-nilai yang dikehendaki oleh masyarakat agar dapat menyebar dalam masyarakatnya (lihat Satjipto Rahardjo, Hukum dan Perubahan Sosial: Teori dan Praktek di Indinesia"(Bandung: Alumni, 1979). 
Aliran developmentalism yang menempatkan hukum sebagai perangkat pembangunan, dalam konteks UUPA menimbulkan peminggiran terhadap eksistensi dan peran komunitas adat dalam tenurial system" yang sudah lama hidup terintegrasi dalam kehidupan bangsa Indonesia. Amanat UUPA yang menempatkan negara sebagai "Negara yang Netral" dalam konsep Hegel telah diselewengkan menjadi negara yang berpihak kepada sekelompok elit penguasa, -dalam hal ini adalah para investor, konglomerat ataupun keluarga pejabat.

Dengan mendalihkan pembangunan dari rakyat dan untuk rakyat, maka atas nama pembangunan pula pemerintah telah memberikan berbagai hak untuk memanfaatkan dan mengeksplorasi sumbersumber agraria kepada segelintir orang, yaitu investor. Kebijakan yang tidak memperhatikan aspirasi dan kepentingan masyarakat lokal dalam memberikan atau mendelegasikan sebagian HMN pada akhimya telah merampas dan memasung eksistensi dan peran lembaga-lembaga adat yang secara idiil sangat dihormati oleh para pendiri republik. Dus, selama berkuasanya rejim Orde Baru telah banyak kebijakan di bidang keagrariaan (baik menyangkut pertanahan, kehutanan, pertambangan, dan lain-lain) yan! menyimpang dari semangat UUPA yan! memberikan kekuasaan penuh untul kesejahteraan rakyat secara keseluruhan sebagai contohnya adalah Hak Penguasaal Hutan (HPH), Hak Pengelolaan Tanamaı Industri (HPTI), dan Konsesi Pertambangal yang lazim dilakukan melalui Kontrak Kary; (KK).

Pengalaman seperti ini tentu saja tida boleh dilanjutkan dan harus diselesaika! secara cepat. Artinya, dalam aspek normat sentralisme kekuasaan sebagaimana tersebı dalam UUPA harus segera dibatasi, sekaligu sengketa tenurial yang sekarang terjadi haru diselesaikan secara adil dan bijaksan. (Wisdom).

\section{Urgensi Pluralisme Hukum Agraria}

Konsep pluralisme hukum dape dikelompokkan dalam 2 (dua) tipologi yait pertama, konsep pluralisme hukum yan didasarkan pada ideologi sentralisme hukur (ideology of legal centralism), yang banya mendominasi pemikiran hukum dan stud studi ilmiah hukum yang bersifat sosiologis dan kedua, konsep pluralisme hukum yan didasarkan pada penglihatan hukum da

"James C. Ridell Memaknai Sistem Tenurial sebagai sekumpulan atau serangkaian hak-hak. "Tenul System is a bundle of rights", katanya. Maksudnya tentu sekumpulan atau serangkaian hak untuk memanfaatke sumber-sumber agraria yang terdapat dalam suatu masyarakat yang secara bersamaan juga memunculka sejumlah batasan tertentu dalam proses pemanfaatan itu. Selanjutnya secara lebih jauh Ridell menjelaské bahwa dengan pengertian sebundel atau serangkaian, maka masing-masing hak dapat dipisahkan dari ikatann lalu diletakkan tidak lagi dalam ikatan asalnya atau diletakan dalam kontek yang berbeda. Ikatan itu send menunjukan adanya suatu sistem. Menurut Ridell setiap Tenure Sytem, masing-masing hak yang dimaksı setidaknya mengandung 3 komponen, yaitu: 
kacamata antropologi. Menurut Marc Galanter, ideologi sentralisme hukum adalah:12

A picture in which state agencies (and their leaming) accupy the center of legallife and stand in a relation of a hirarchic control... to other, lesser normative orderings such as the family, the corporation, the business network.

Dalam kerangka tersebut hukum merupakan dan seharusnya hukum negara, yang seragam untuk semua orang, eksklusif dari seluruh hukum lain, dan diadministrasikan oleh seperangkat institusi-institusi negara. Aturan-aturan lain yang tingkat normatifnya lebih rendah, seperti gereja, keluarga, perhimpunan-perhimpunan sukarelawan dan organisasi-organisasi perekonomian secara hirarkhis subordinat terhadap hukum institusi- institusi negara. ${ }^{13}$ Pandangan antropologis mengemukakan bahwa hukum bukanlah semata-mata dalam pengertian negara, akan tetapi otoritas atau institusi-institusi. Menurut Pospisil, pluralisme hukum terwujud dalam apa yang disebut legal levels (tingkatantingkatan hukum). ${ }^{14}$ Menurutnya sistem-sistem hukum menciptakan suatu hirarki yang mencerminkan derajat ketermasukan (inclusiveness) dari subkelompok-subkelompok yang sama. Keseluruhan sistem hukum dari subkelompok-subkelompok yang jenis dan derajat ketermasukannya sama (misal, keluarga, keturunan, masyarakat, konfederasi politik) inilah yang disebut legal levels. Tidak ada satu masyarakatpun yang mempunyai satu sistem hukum konsisten yang tunggal. Masyarakat umumnya mempunyai sistemsistem hukum sebanyak subkelompoksubkelompok yang berfungsi. ${ }^{15}$

(i) Subjek hak, yang berarti pemangku hak atau pada siapa hak tertentu dilekatkan. Subjek hak berpariasi dari individu, rumah tangga, kelompok, komunitas, kelembagaan sosial ekonomi, hingga lembaga politik setingkat negara;

(ii) Objek hak, yang berupa persil tanah barang-barang yang tumbuh diatas tanah, barang-barang tambang atau mineral yang berada di dalam tanah atau perut bumi, perairan, tandungan barangbarang mahkluk hidup dalam suatu kawasan perairan, maupun suatu kawasan atau wilayah udara tertentu. Objek hak harus bisa dibedakan melalui alat tertentu dengan obyek lainnya. Untuk objek hak berupa suatu persil atau kawasan perairan, batas-batasnya biasanya diberi suatu simbol. Objek hak bisa bersifat total bisa juga parsial. Misalnya, seseorang yang mempunyai hak atas pohon sagu tertentu, tidak dengan sendirinya mempunyai hak atas tanah dimana pohon sagu inj berdiri; dan

(iii) Jenis hak, setiap hak selalu dapat dijelaskan batasannya, yang membedakan dengan hak lainnya. Dalam hal ini jenis-jenis hak merentang dari hak millik, hak sewa, hingga hak pakai dan lain sebagainya, tergantung pada bagaimana masyarakat yang bersangkutan menentukannya. Setjap jenis hak memiliki hubungan khusus dengan kewajiban tertentu yang dilekatkan oleh pihak lain (mulai dari individu sampai negara) dan berlaku dalam suatu kurun waktu tertentu.

${ }^{12 M a r c ~ G a l a n t e r, ~ " J u s t i c e ~ i n ~ m a n y ~ R o o m s: ~ C o u r t s, ~ P r i v a t e ~ O r d e r i n g, ~ a n d ~ I n d i g e n i u s ~ L a w, " ~ J o u m a l ~ o f ~ L e g a l ~}$ Pluralism, Vol. 19 Tahun (1981), hlm 17 dalam Nandang Sutrisna, Pluralisme Hukum dan Signifikansi Sosial Hukum: Studi tentang Penggunaan Hukum dan Pengaruh Hukum terhadap Perilaku, ${ }^{\text {}}$ Tesis Program Pascasarjana UNAIR Surabaya, 1994.

13/bid.

14J. Griffiths, "what is Legal Pluralism?' Joumal of Legal Pluralism and Unofficial Law, Vol. 24 Tahun (1985), hlm. 9. ${ }^{15}$ Ibid. 
Sebagaimana telah dijelaskan dalam paparan sebelumnya bahwa realitas empirik bangsa Indonesia adalah majemuk. Kemajemukan ini selaras dengan konsep pluralisme hukum (kemajemukan hukum). Perhatian atas gejala kemajemukan hukum bukan saja dapat diartikan sebagai perhatian terhadap beberapa hukum lain yang diakui oleh sistem hukum resmi (State Law) melainkan secara lebih jauh juga menyangkut hal yang menggambarkan perhatian dan pengakuan pada fakta bahwa berbagai macam sistem hukum exist pada lingkupnya masing-masing, dan dapat berlaku di luar ketentuan negara. Masing-masing sistem hukum memiliki sumber dan perkembangan sejarah yang berbeda. Mereka berbeda dalam kerangka klasifikasi dan konsep-konsep khusus, serta mempunyai cara-cara yang khas dalam mempersepsikan dan menafsirkan realitas yang ada.

Dalam aspek tertentu legal pluralism itu berlawanan dengan ide legal cetralism yang menyatakan bahwa negara memonopoli hukum dan menolak bentuk-bentuk hukum lainnya. State Law seperti diketahui adalah hukum uniform untuk seluruh penduduk sehingga diatur oleh sistem tunggal oleh institusi negara, dan bahwa hukum lainnya hanya exist bila diakui oleh State Law tadi. Ide legal pluralism kemudian berkembang ke arah penolakan dominasi State Law terhadap berbagai aturan hukum lainnya yang pada kenyataannya memang banyak terdapat di berbagai suku-suku bangsa tertentu. Dalam kontek hukum agraria, dominasi tersebut biasanya akan mengubah tatanan Tenure System masyarakat lokal.

Tidak dapat dipungkiri bahwa gejala kemajemukan dalam kehidupan bangsa
Indonesia bukanlah suatu yang baru da asing sama sekali. Semboyan negar: "Bhineka Tunggal lka", menunjukkan semangi itu. Hal yang sama juga tampak pada perangki peraturan perundang-undangan nasioni yang mengatur masalah perkawinan, da pewarisan.

Berdasarkan realitas empirik maupu realitas simbolik tersebut di atas mak membahas kemungkinan adanya pluralism hukum agraria merupakan sesuatu yan realistis. Hanya saja yang perlu dihinda adalah sikap-sikap diskriminatif, sebagaiman yang pernah terjadi pada era pluralisme huku di jaman kolonial. Dengan demikian, jika pad masa kolonial pluralisme terjadi pada tataré vertikal, maka semangat pluralisme hukul agraria yang dimaksud ini mengarah pad pluralisme horizontal. Tanpa mengurangi as dan atau mengesampingkan semang: persatuan dan kesatuan bangsa Indonesia.

Dengan pandangan ini, sebenarny hukum adat yang sebelumnya hany dikategorikan folk law diubah statusny menjadi state law yang berlaku dalam sua sistem sosial tertentu, yang pelaksanaanny tetap tunduk pada peraturan perundange nasional yang ada.

Berdasarkan uraian pemikiran tersebut atas kiranya dapat disimpulkan bahwa dala sistem hukum negara kesatuan Republik h donesia masih dimungkinkan adany pluralisme hukum yang tidak bertentange dengan jiwa dan hakekat konsep negal kesatuan. Oleh karena itu, dalam rangk melakukan reformasi UUPA -sebagai prodı hukum transisi dari hukum kolonial menja sistem hukum nasional yang mencerminke realitas kemajemukan, kiranya urgensi pluralisn hukum agraria dapat diimplementasikan. 


\section{Simpulan}

Eksistensi UUPA sebagai produk hukum di bidang agraria bersifat transisional yang dalam prinsip dasamya memberikan kekuasaan atau wewenang yang sangat luas kepada negara (HMN). Dalam praktek implementasi HMN banyak menimbulkan problematika yang sangat serius berkaitan dengan ekses munculnya disintegrasi bangsa sebagaimana fenomena yang sekarang mulai muncul yaitu sengketa tenureal. Dalam rangka merespon tuntutan masyarakat adat akan perlunya jaminan akan eksistensi tenureal sistem dalam kehidupan berbangsa dan bernegara, maka keharusan merumuskan pluralisme hukum di bidang agraria merupakan sesuatu yang urgen. $\square$

\section{Daftar Pustaka}

Budiman, Arief. Teori Negara: Negara, Kekuasaan dan Ideologi. Jakarta: Gramedia, 1996.

Ihromi, TO. Antropologi Hukum: Sebuah Bunga Rampai, Jakarta: Yayasan Obor Indonesia, 1993.

Kasim, Ifdhal.Tanah Sebagai Komoditas Strategis. Jakarta: ELSAM, 1995.

Konsursium Reformasi Hukum Nasional. Usulan Revisi UUPA, Menuju Penegakan Hak-hak rakyat Atas Sumber-sumber Agraria. TTp: Tp, 1998.

Mudjiono. Hukum Agraria. Yogyakarta: Liberty, 1992.
Rahardjo, Satjipto. Hukum dan Perubahan Sosial: Teori dan Praktek di Indonesia. Bandung: Alumni, 1979.

Manan, Bagir. Dasar-Dasar Perundangundangan yang Baik. Jakarta: IND-HILL. CO, 1992.

Soetandyo Wignyosoebroto. "Pembaharuan Agraria: Apa yang Perlu Diagendakan". dalam Usulan Revisi UUPA, Konsursium Reformasi Hukum Nasional dan Konsursium Pembaharuan Agraria, Jakarta, 1998.

HE. Zenal Abidin. "Kepentingan Umum sebagai Alasan Pencabutan/Pembebasan Hak atas Tanah di Daerah Istimewa Jogyakarta". Laporan Penelitian Lembaga Penelitian UII Jogjakarta, 1991.

Kenneth. Administrative Law. New York: West Publishing Co, 1992.

Quade, E, S. Analysis for Public Decicion. New York: North-Halland, 1982.

Marc Galanter. "Justice in many Rooms: Courts, Private Ordering, and Indigenius Law". Joumal of Legal Pluralism, Vol. 19 Tahun 1981.

Nandang Sutrisno. Pluralisme Hukum dan Signifikansi sosial Hukum: Studi tentang Penggunaan Hukum dan Pengaruh Hukum terhadap Perilaku". Tesis Program pascasarjana UNAIR Surabaya, 1994.

J. Griffiths. "what is Legal Pluralism?' Joumal of Legal Pluralism and Unofficial Law, Vol. 24 Tahun (1985).

\section{మా}

